\title{
Civilisations
}

Revue internationale d'anthropologie et de sciences

humaines

$49 \mid 2002$

Pain, fours et foyers des temps passés

\section{Investigating the Prehistoric Bread of Northern}

Greece

The archaeobotanical evidence for the Neolithic and the Bronze Age

Soultana-Maria Valamoti

\section{(2) OpenEdition}

Journals

Édition électronique

URL : http://journals.openedition.org/civilisations/1359

DOI : 10.4000/civilisations. 1359

ISSN : 2032-0442

Éditeur

Institut de sociologie de l'Université Libre de Bruxelles

Édition imprimée

Date de publication : 3 juin 2002

Pagination : 49-66

ISBN : 0009-8140

ISSN : 0009-8140

Référence électronique

Soultana-Maria Valamoti, « Investigating the Prehistoric Bread of Northern Greece », Civilisations [En

ligne], 49 | 2002, mis en ligne le 01 juin 2005, consulté le 03 mai 2019. URL : http://

journals.openedition.org/civilisations/1359; DOI : 10.4000/civilisations.1359

Ce document a été généré automatiquement le 3 mai 2019.

(c) Tous droits réservés 


\section{Investigating the Prehistoric Bread of Northern Greece}

The archaeobotanical evidence for the Neolithic and the Bronze Age

Soultana-Maria Valamoti

I wish to express my gratitude to all the archaeologists who have entrusted me with the study of the archaeobotanical material on which this paper is based: Mr Manthos Bessios, Mr Panagiotis Chrysostomou, Dr Pavlos Chrysostomou, Dr Nikos Efstratiou, Dr Dimitris Grammenos, Ms Dina Kallintzi, Dr Kostas Kotsakis, Dr Chaido Koukouli-Chrysanthaki, Dr Aikaterini Papanthimou-Papaefthimiou, Mrs Maria Pappa and Dr Angeliki Pilali. I would also like to thank Dr Glynis Jones and Dr Mike Charles for their constant help and advice on identification of the archaeobotanical material and Ms Tania Gerousi, Dr Yiannis Hamilakis, Dr Sarah Mason, Dr Jutta Meurers-Balke, Dr Mark Nesbitt and Dr Delwen Samuel for the very useful and interesting references they made available and to which this paper owes much. I also thank Dr N. Efstratiou, Dr Y. Hamilakis and Dr M. Nesbitt for the valuable critical comments.

\section{Introduction}

\subsection{Bread}

1 Bread in modern Greek diet is a very important food that accompanies almost every meal, even meals that consist of other starchy food like pasta and potatoes. «To earn one's bread» (kerdizo to psomi mou) means to earn ones living, the expression underlining bread's importance in subsistence. This close connection between food and cereals has been known since Homer's time (Braun 1995). Today bread is mainly a commodity bought at the market, rather than made at the household level. A few places still remain, however, where bread is both home-made and bought at bakeries (rural areas), or where bread is mainly home-made (e.g. Olymbos Karpathou, Filipidis 1994).

Despite the recent re-introduction of wholemeal bread, or bread made of rye or maize («bobota»), influenced by the "health food» trend, white wheaten loaves of raised, leavened bread dominate modern Greek bakeries; they are «bread» par excellence. 
Wheaten leavened bread has a long tradition in this part of the world. It has been made and sold at bakeries since at least classical times; it was then an expensive foodstuff, not accessible to the majority of the people (Micha-Lampaki 1984).

Wheaten flour, however, is not the only main ingredient that can be used in breadmaking and the same applies to leavening. Other cereals such as barley, millet, oats, rye, can also be used. Barley and millet were used in antiquity but the latter was a rare ingredient (Micha-Lampaki ibid.). All these cereals were used in Byzantine times for making bread (Koukoules 1952). Bread made of pulses, such as lentils and chick peas ground into meal, is also known [Micha-Lampaki ibid. (antiquity), Koukoules ibid. (byzantine period), and Dalianis 1993 (modern times)]. Acorns are also known from recent times (Polymerou-Kamilaki 1994, p.415). Leavening involves the use of yeast or sourdough, which «converts the cereal grains from a nutritionally limited source of proteins and vitamins to an outstanding source of human nutrition " (Katz and Voigt 1986). Unleavened breads require only that a thick mixture of pounded cereal and water be heated " (ibid.). Such breads are nowadays made in the Middle East and India (Avitsur 1977, Katz and Voigt ibid., Lerche 1981) and were also known in Greece during classical times (5th-4th centuries BC, Micha-Lampaki ibid.). In the classical period, bakeries and professional bread makers become established (Micha-Lampaki ibid., p.29) and an impressive variety of breads appears to exist as regards ways of baking, shape of bread, ingredients and origin (ibid., p.33).

\subsection{Cereal food other than bread}

4 Bread is only one way of consuming cereals. Other cereal foods (e.g. gruel, porridge, cracked wheat, bulgur, frikke), could have been the «bread» in certain periods in the past. In an investigation of modern recipes of the Mediterranean it was observed that partly-ground cereal grain, little transformed and not reduced to flour (e.g.cracked wheat, bulgur), was a very widespread ingredient (Rivera-Nunez and Obon de Castro 1989). On the contrary to any concept of bread we may have nowadays (i.e. wheaten, leavened, baked), was the "maza » of the ancient Greeks, a very popular food made of barley meal, the preparation of which did not involve either leavening or baking (MichaLampaki 1984, Braun 1995). 
Fig. 1 - Northern Greece, Macedonia and Thrace. Sites mentioned in the text : 1 . Servia, 2. N. Nikomedeia, 3.Makriyialos, 4.Mandalo, 5.Giannistsa B, 6.Kastanas, 7.Assiros, 8.Thermi B, 9.Olynthos, 10.Sitagroi, 11.Arkadikos, 12.Dikili Tash, 13.Makri

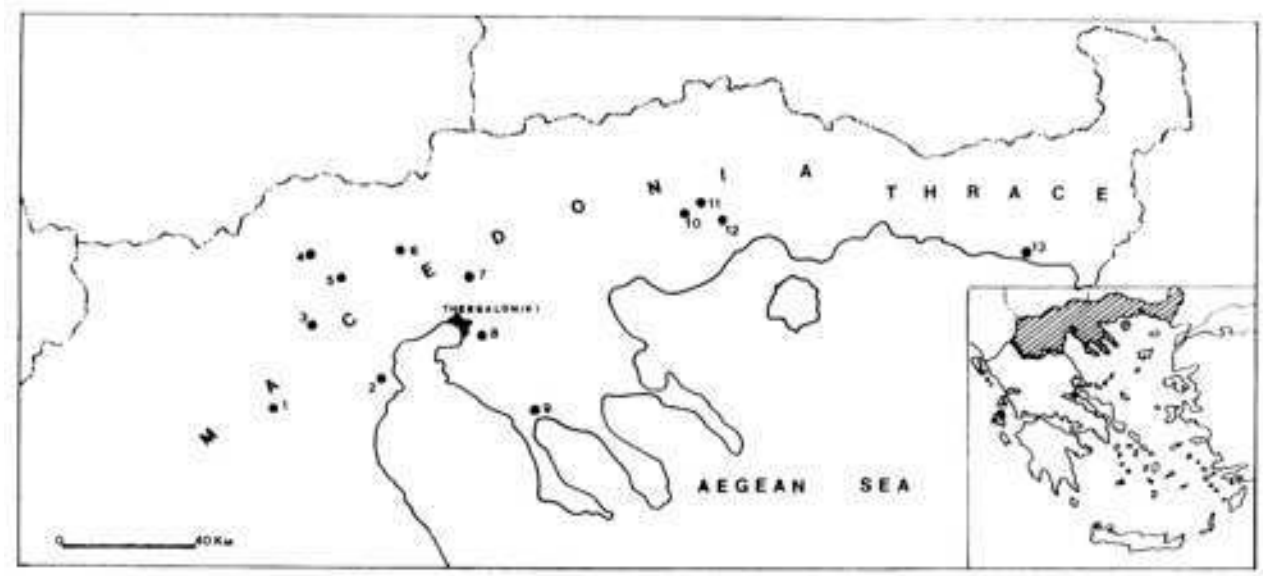

\subsection{Prehistoric bread}

Although bread per se or other cereal based foodstuffs can be traced back in time as early as Homer (Moritz 1958, p.35), for prehistoric times the situation is much less clear. Some reference to cereals and flour is made in the Linear B texts refering to the Late Bronze Age Palaces of southern Greece (Palmer 1992 and Halstead 1995). The only direct archaeological evidence for bread are the millet-bread finds from Marmariani in Thessaly (Renfrew 1973, p.193, refering to Vickery 1936).

In the broader sense of «cereal food", the bread of prehistoric northern Greece is investigated here. This paper forms an attempt to investigate the contribution of the cereals, found in prehistoric settlements of northern Greece, to human diet. It examines the ingredients of prehistoric « bread», i.e. the cereals intended for human consumption, whether they differed between sites and through time and how they were processed or consumed.

\section{Archaeobotanical evidence from Macedonia and Thrace}

7 The bulk of the evidence as regards the contribution of cereals in prehistoric diet is provided by the archaeobotanical record. On Greek sites this consists mainly of charred plant remains incorporated in the archaeological deposits. Despite the great potential of plant remains in providing information on the possible ingredients of prehistoric "breads ", archaeological research in Greece has, in most cases, neglected this direct source of evidence on food ingredients. Northern Greece, during the past decade (Andreou et al. 1996), has experienced an intensive archaeological investigation of prehistoric sites which has coincided with an interest in the retrieval of archaeobotanical data and the presence of native specialists.

Consequently, this has resulted in a dramatic increase of archaeobotanical data in the area, mainly in the regions of Macedonia and Thrace. These newly available data allow for 
a more detailed investigation of the role of cereals in prehistoric diet ${ }^{i}$. For this reason, northern Greece is the area chosen to be discussed in this paper.

Published archaeobotanical evidence for Macedonia and Thrace in northern Greece (fig. 1) could be summarised as patchy, with each periodii being represented by charred plant remains from one or two sites, and in most cases by few samples only. Until recently, seven prehistoric sites of northern Greece (TABLE 1) had been investigated archaeobotanically: Nea Nikomedeia (early Neolithic, van Zeist and Bottema 1971), Servia (Middle Neolithic, Hubbard 1979), Olynthos (Late Neolithic, Mylonas 1929), Sitagroi (Late Neolithic/Early Bronze Age, Renfrew 1971 and 1973) and Dikili Tash (Late Neolithic/Early Bronze Age, Renfrew 1979), Assiros (Early/Late Bronze Age, Jones et al. 1986) and Kastanas (Early/Late Bronze Age, Kroll 1983). Of these sites only few have been extensively sampled and have yielded large numbers of charred plant remains, and only Kastanas has been fully published.

10 The cereal species identified from these sites are summarised in Kroll (1991) and Halstead (1994) (Table 1). For the early Neolithic, einkorn (Triticum monococcum), emmer wheat ( T. dicoccum) and naked six row barley (Hordeum vulgare var. nudum), are present at the site of Nea Nikomedeia. The same species have been identified from Middle Neolithic Servia. At Sitagroi, besides the presence of einkorn, emmer and six-row hulled barley, freethreshing wheat (T. aestivum/durum) appears during the Late Neolithic. Millet (Panicum miliaceum) and wheat not identified to species are reported from Late Neolithic Olynthos. The same range of species appears in the Bronze Age with the addition of spelt wheat ( Triticum spelta) which is present at Kastanas since the Early Bronze Age and at Assiros in the Late Bronze Age ; no naked barley is reported from this period.

11 As Halstead (1994) points out, the mere presence of a species in the archaeobotanical record is not a direct indication that this species was a deliberately grown crop. Of the annual cultigens attested archaeo- botanically, deliberate cultivation can only be inferred for major components of cleaned crop products or dehusking residues (Dennell 1976) and less satisfactorily for those found in more or less pure "caches » (Halstead ibid). The cereal crops for Neolithic northern Greece, identified so far, are the following : einkorn, emmer, naked barley, wheat indet and millet. In the Bronze Age spelt wheat, bread/ durum wheat and hulled barley appear on the crop list (Halstead, ibid.).

To the above information, new data from 7 more prehistoric sites can now be added. The sites are: Makriyialos (Bessios and Pappa 1997), Giannitsa B (Crysostomou and Chrysostomou 1993) and Mandalo (Pilali et al. 1983) in western Macedonia, Thermi B in central Macedonia (Grammenos et al. 1992), Arkadikos (Peristeri and Touloumis 1994) and Dikili Tash (Koukouli 1996) ${ }^{\text {iii }}$ in eastern Macedonia, and Makri in Thrace (Efstratiou 1993)iv . Giannitsa B is dated from the Early Neolithic to the Final Neolithic. All the other sites have Late Neolithic deposits. Dikili Tash and Mandalo also have Early Bronze Age deposits. A wide range of species has been identified from each site. Cereals constitute a large component of the assemblages, in some cases the main one (other finds include vegetables, fruit etc). These new cereal finds, combined with the already existing evidence, allow for an attempt to further investigate the contribution of cereals to the prehistoric diet in the region. At the same time, they ask interesting questions that deserve further investigation.

The overall picture in terms of the species present at the above sites does not differ much from the one already given in Kroll's and Halstead's summarised information (see above and tableau 1) : Einkorn, emmer, cf. bread wheat, bread/durum wheat, two and six row 
barley of the naked and hulled varieties are present. Only three seeds of millet have been found, at Giannitsa, Mandalo and Dikili Tash (one at each site!). Another glume-wheat species is also present in the assemblages, a subject currently under investigation (Jones et al. forthcoming). As Hillman et al. (1996) point out, » we should consider the possibility that taxa which are no longer extant were present in the past». This may well be the case for certain glume bases found at Makri, Arkadikos and Makrygialos, the morphological characteristics of which, do not allow its identification as either einkorn, emmer or spelt on the basis of available criteria used for the distinction of the three glume wheat species (Jacomet 1987).

14 A list of species, however long, can be of little use to the study of aspects of prehistoric life in northern Greece. A step further is to identify the crops ${ }^{v}$, i.e. the species that were deliberately grown and used, which would result in another, perhaps more meaningful list. Regional or diachronic differences in crop choices could emerge, which could in turn contribute to our better understanding of differences in settlement pattern observed on a regional scale and of changes occurring on a temporal scale.

\section{Cereal crops}

\subsection{Glume wheats}

15 Einkorn and emmer are crops found on all sites with the exception of Dikili Tash, where only einkorn is present. This is indicated by samples consisting almost entirely of large numbers of glume bases and spikelet forks, i.e. the by- products of einkorn and emmer dehusking. These are present either in floor deposits or in the ash debris of hearths and ovens. At Mandalo and Dikili Tash, cereals are present as pure grain caches, possibly in stored contexts. At Giannitsa B processing by-products of einkorn and emmer occur in Early Neolithic deposits and a pure grain cache of einkorn in Late Neolithic deposits.

\subsection{Free-threshing wheat}

16 The situation with free-threshing wheat is not so clear. Rachises of either durum or bread-wheat occur at Makri, Arkadikos, Thermi B, Makriyialos and Giannitsa B. At Makri and Thermi, few rachis internodes with better preservation than the rest, have been identified as possible bread-wheat. On the whole, rachises of free-threshing wheat occur in few samples and in very low numbers. Grain of free-threshing wheat is also present in very low numbers at Makri and Arkadikos.

The question that arises from the free- threshing wheat finds is whether they represent crops in their own right or commensals of the emmer, einkorn or barley crops. The occurrence of cultivars as contaminants of crops is not uncommon. Bitter vetch, for example occurred in ethnographic samples from Amorgos as a major contaminant of other legume crops, although the species had not been grown on the island for several years (Jones and Halstead 1995, p.111). If free-threshing wheat were a commensal of einkorn and emmer fields, was it derived from bread/durum wheat grown in the same area, on fields of these sites in the past, or was it a commensal in fields of other areas, where free- threshing wheat was or had been a crop (was therefore more common there), and from which cereal grain had at some stage been transported to our sites? Such issues 
may be clarified with the progress of the analysis of the archaeobotanical material and with more archaeobotanical data from the region.

\subsection{Barley}

Barley is present at all sites. Two-row barley (Hordeum distichon) was identified on the basis of rachis finds at Makriyialos, Arkadikos and Makri. Hulled and naked grains occur with these rachises and it is not possible to determine whether hulled and/or naked forms of two- row barley are present. At Arkadikos there is an indication that two- row barley both hulled and naked are present : although the vast majority of the gains could not be identified as either twisted or straight because of the distortion caused by charring, definite straight grains, both hulled and naked ${ }^{\mathrm{vi}}$, were identified in very low numbers compared to the number of barley grains present in the samples; no twisted grains were identified, however, and, the overall impression was that the barley grains must have been straight : although charring can make straight grains look like twisted, the reverse seems rather unlikely. Six- row barley was identified at Mandalo, Dikili Tash and Makri : at Mandalo and Makri on the basis of both rachises and twisted grain, and at Dikili Tash on the basis of grain. At Mandalo six- row barley was of the hulled variety whereas at Dikili Tash of the naked variety, as the presence of hulled twisted grains and naked twisted grains, respectively, suggest. At Mandalo, Dikili Tash and Arkadikos, barley has been found as pure caches of grain, indicating that the species was a crop. That barley was a crop at Makri is indicated by barley rachises outnumbering barley grain in one sample, representing the by-products of barley processing. At Makriyialos, it is not clear yet whether two-row barley was a crop in its own right or a commensal. Barley species and varieties, where these are identifiable, seem to differ between sites.

\subsection{Millet}

Millet does not seem to have been a crop in the Neolithic. Its occurrence as a crop at Olynthos, where it was found as the contents of a minature vase, is unique (Mylonas 1929). By contrast, it is found as a crop in the Late Bronze Age both at Assiros and Kastanas (Halstead 1994).

\section{Cereal food versus fodder}

Distinctions between food and fodder seem to vary a lot and depend on the food trends of a certain period in time, and also on particular circumstances of hardship that households or communities have to face. They also depend on what researchers think of as edible and inediblevii. Cereals can be grown both as food and fodder and the distinction between human food and fodder seems a fairly flexxible one, depending on socioeconomic factors. What in a good year, in terms of wheat yields, can be called fodder (e.a. a maslin of wheat and barley rich in barley), in a bad year can be called food (Jones and Halstead 1995). Although traditionnally wheat has come to be associated with human food and barley with fodder, Braun (1995) points out that in Greek epic, barley is both food and fodder, but wheat is fodder only, fed to horses owned by mythical heroes and geese intented for the royal table. 
21 The majority of archaeobotanical data from northern Greece that were available until now (with the exception of Kastanas, see Halstead, 1994, p.24) consisted of cleaned products at the final processing stages, and although we can assume that they were used as human food, we cannot demonstrate that this was the case. They could equally have represented cleaned grain for sowing, or grain intended for use as fodder. The majority of the samples from Makri, Thermi B, Giannitsa B and Makriyialos, as well as samples from Arkadikos, consist of the by- products of the final stage of einkorn and emmer dehusking. The abundant evidence of dehusking takes us one step further from the mere identification of their cultivation as crops. It can be suggested that einkorn and emmer were used primarily for human consumption as the tedious and time consuming process of dehusking, i.e the removal of the glumes that surround the grain, would have been unnecessary had these species been intended as animal fodder. This is also supported by ethnographic observations which demonstrate that when these species are fed to animals they are given as spikelets either intact, or partly ground or pounded prior to feeding (Nesbitt et al. 1996, p. 242). Einkorn and emmer were therefore certainly used as human food (vs fodder) in those sites. The possibility of their additional use as fodder, however, cannot be dissmissed.

Free- threshing cereals, because they do not require any further processing beyond the sequence of the threshing floor (Hillman 1985) in order to free the grain from straw and chaff, do not leave such clues as to their intended use. Both durum and bread- wheat have always been considered as cereals for humans. Bread-wheat in particular, as its name implies, has been the species most suited for the preparation of our modern raised loaves of wheaten bread. Their position as crops however, is attested only for the Late Bronze Age, several millenia later than the few rachis fragments and grain that occur at the neolithic sites. Where these species have been found as crops we can assume their use as food but we must keep an open mind for Gods, Heroes and their Horses !

Hulled barley, whether intended for human or animal consumption needs to be hummelled in order to remove the basal bit of the awn (Hillman ibid, p. 20). Hummelling is performed on cleaned grain which means that even when this crop was used for animals it would have undergone most processing stages, except hand cleaning and dehulling. In this respect naked barley would have had an advantage, unless a hulled variety without awns (e.g. the trifurcatum, ibid.) was known in prehistoric times in the area. It is not known of course whether this awnless variety, which until 10 years ago was grown at the Skourta Plain (halfway between Athens and Thebes) under the name "soutiko", existed in prehistoric times. Barley grain may be crushed when it is used for fodder (Halstead and Jones 1989), suggesting that animal fodder preparation can be quite elaborate and time consuming (cf. hulled wheats). The archaeobotanical evidence available from northern Greek sites does not provide any indications for the intended use of barley.

\section{Hulled versus free-threshing wheat}

The overall picture obtained from the sites of prehistoric northern Greece is that einkorn, emmer and barley were grown as crops. As regards free-threshing wheats, their occurrence, at least in the Neolithic, is rare by comparison to hulled wheats and barley. Could this picture be an outcome of taphonomic factors? Free- threshing cereals have always been thought of as under- represented in the archaeobotanical record, as it was 
assumed that their preparation for consumption, unlike the glume wheats, did not require contact with fire (Dennell 1976). Parching of glume wheats has been regarded as a step prior to dehusking and this has been considered as a source generating charred glume wheat finds in archaeobotanical assemblages. This widely held view has recently been questioned (Nesbitt and Samuel 1996), drawing on archaeological, archaeobotanical, ethnographic and experimental evidence. As Meurers-Balke and Luening (1992) demonstrated in a series of experiments, parching is unnecessary for dehusking. Furthermore one could add that parching or roasting could equally have been applied to free- threshing cereals, as a means of preparing grain for consumption (e.g. frikke, roasted grains, flour from roasted grain, Hillman 1985, p. 12). Hillman points out that roasting of free- threshing wheat grain, generates quite a few charred grains which are then discarded. Thus hulled and free/threshing grains are equally likely to be preserved in archaeobotanical samples. The limited presence (e.g. Arkadikos) or complete absence (e.g. Mandalo, Makriyialos, Dikili Tash) of free-threshing wheat grain at the majority of neolithic sites in northern Greece where glume wheat grain is abundant or present, may, therefore, be reflecting the actual situation, i.e. the rarity of free-threshing cereals as crops. Only at Late Bronze Age Assiros does free-threshing wheat grain occur as a crop. Further south, in Thessaly, it is found as a crop at an earlier date, in late neolithic Sesklo (Halstead 1994).

Free- threshing wheat chaff on the other hand, is likely to be under- represented due to its behaviour during charring. Free-threshing wheat rachises, have proved, experimentally, to be more sensitive to charring conditions (i.e. temperature and oxygen supply) than their glume wheat counterparts and wheat grain (Boardman and Jones 1990). In addition to this, several free-threshing chaff components such as light rachis segments, straw internodes and light straw nodes are likely to burn to ashes (Hillman 1984 b, p.11) unlike glume bases and spikelet forks which "drop quickly through the flames and into the ashes without being burnt to ash themselves" (Hillman 1981, p. 140). Nevertheless, the shorter rachis fragments and especially the dense basal segments, do behave in the same way as glume bases (ibid.). Despite therefore the various factors that may be causing an under-representation of free-threshing wheat chaff, it is unlikely that at a site where such cereals were grown, chaff remains would not have been incorporated in the settlement's deposits (cf. Hillman 1981, p. 142). Free-threshing wheat chaff is either rare or absent from neolithic sites in northern Greece. This is the case even at some of the sites under study, where glume-wheat chaff remains dominate the vast majority of the samples, such as Makriyialos and Makri, and where one would expect free- threshing chaff to be more common had it been extensively used at the site in ways similar to glume-wheat chaff (as fuel for example). The chaff evidence, like the grain, is indicating that free-threshing wheat may not have been a crop in the area, at least during the Neolithic.

The picture that emerges so far from the archaeobotanical record indicates a dominance of glume wheats, reflecting perhaps their position as staple cereals and the actual food choices and/or availability of species. Bread/durum wheat was known in Greece since prehistory but was generally ignored. The species perhaps became appreciated when the necessary technology to transform them into something interesting to have on ones table, became available. This may have provided a strong motivation, besides the species' productivity, growth requirements etc. Unfortunately archaeobotanical studies from the historic period, especially for classical times onwards, are very scarce indeed. When and if 
they appear in the future, they could provide useful comparative material to what is already available for preceding times. It could then be possible to examine whether the documented use of free-threshing cereals in Late Antiquity is reflected in the archaeobotanical record.

\section{Beyond the cleaned grain}

\subsection{Processing for consumption}

Potentially all cereal species that have been retrieved from prehistoric sites in northern Greece could be reduced to smaller parts of differing sizes according to the food that would have been prepared. The tools necessary for this job would have been the pestle and mortar, and the saddle quern. The pestle and the mortar are generally associated with dehusking and the saddle quern with grinding (Hillman 1984 a, pp.129-131, Samuel 1989, pp.258-270). Mortars and pestles made of stone are not reported from prehistoric sites from northern Greece (T.Gerousi pers. comm); had they been made of wood they would have only survived under waterlogged conditions. At the site of Thermi B, a clay construction which consists of a flat clay surface at floor level, surrounding a clay cylindrical recipient of $11 \mathrm{~cm}$ depth and $25 \mathrm{~cm}$ width, placed below floor level (Grammenos et al. 1992, p. 392), could have been used in a way similar to a pestle and a mortar (cf. Hillman 1984 a, p. 130). Saddle querns (Demoule and Perles 1993) occur quite commonly at prehistoric sites in northern Greece, and although we cannot infer from their mere presence that they were used for grinding cereals, we can at least be sure that had these people wanted to grind cereal grains, the necessary technology was available. If such a thing as a cooking accident existed, then in middens, one ought to find bits of grain processed for gruel, cracked wheat etc. This ought to be recognisable on the morphology of the grain (Lunning and Meurers Balke 1992, p.350 refering to Knoerzer 1981).

Crushed cereal grains could have been eaten as gruel or porridge. A rather sophisticated preparation of cereal grain is bulgur (Hillman 1984) whereby wheat grain is boiled, then sun-dried, the bran subsequently removed and the remaining grain kernels cracked and then sieved. The word for bulgur in modern Greek is bligouri or pligouri, a word that is not of Greek origin (Dimitrakos 1956). Such a preparation however was well known in the ancient Greek world under the name of "chondros" (Micha-Lampaki 1984, p.26). Prehistoric evidence of cereal processing in such a way, for human consumption, comes from southern Greece, from the Late Bronze Age site of Akrotiri in Santorini (Cyclades), where a kind of «bulgur» is reported among the archaeobotanical remains (Sarpaki 1987). The Akrotiri «bulgur » was made of barley and consisted of fragmented barley grains which had been broken in a characteristic fashion: " The breakage point of these fragments is very consistent and is transverse to the caryopse, as if some type of repeated perpendicular pressure was applied using probably a pestle and a mortar» (ibid. p. 158). Bulgur however requires parboiling of the grain, whereas cracked wheat [ « korkoto » in modern Greek, deriving from the pontic dialect, « deshishe » in arabic (Avitsur 1977)], is just broken grain which has not undergone parboilling. It is not known which of the two kinds is represented by the Akrotiri finds. It would be interesting to investigate whether such fine differences in the treatment of grain would affect its morphology in ways that may be recognisable on charred material. 
29 All cereal grains could have been reduced to flour and used in bread making. The end products would however have differed as each cereal species possesses different baking qualities (Le Clerc 1918, Moritz 1958, p. xviii). Some authors (Abrams 1978, p.43, McGee 1984, p. 275) consider only bread-wheat as suitable for bread-making. They even state that only when bread wheat started being widely cultivated, bread started being made (McGee ibid.). This is not true at all as flour of other cereals has been used in breadmaking (see introduction). Emmer wheat for example, a glume wheat, was the species used in bread-making in ancient Egypt (Samuel 1993) and spelt wheat is a very popular ingredient of bread making in modern Germany (M. Nesbitt, pers. comm.). Recent tastes do not necessarily apply to the past. Einkorn and emmer wheat, the species that appear to have been the staples during at least the Neolithic in northern Greece, could have been used in bread making.

\subsection{Cooking}

Some hints on the types of « bread » that prehistoric households were preparing could be obtained from remains of cooking facilities and from the kinds of fuel that was used for its preparation.

31 The types of cooking facilities found at sites could provide clues on the types of « breads " that may have been baked: for example, constructions such as the "tannur », i.e. a cylindrical clay structure in which bread is baked against its sides, (Avitsur 1977, Lerche 1981) cannot be used for baking loaves of risen bread. A wide range of « ...hearths, ovens, fire- pits and other features that were probably related to the cooking of food» is reported for the Greek neolithic (Demoule and Perles 1993, p. 377). This may be an indication of a variety in cooking practices. Of course, any absence of oven constructions or hearths does not imply that no bread could ever have been baked on a site. Bread baked directly on ashes was known in antiquity and Byzantine times (" apanthrakis », i.e. baked on embers, Lampaki 1984, p.36 and " psomi stachtokylismeno », i.e. bread rolled in ashes, Koukoules 1952, p. 26), and is still being made in Thessaly (Gourgiotis 1994).

What determines the fuel that is used for cooking is its accessibility, its suitability for the particular cooking facilities of the household (Barnard and Kristoferson 1985), as well as the scale of bread production. Quick burning fires for which straw, chaff, reeds etc. are used, are ideal for small scale baking of flat breads on the "saj", a convex iron surface used for baking bread (Mark Nesbitt, pers.comm.). Similar fuel resources, like straw and/ or dung, would also be used for a type of bread that is baked directly on ashes (Avitsur ibid., Gourgiotis 1994). Traditionally, dung, straw, reeds etc. are the fuel used for baking bread in the "bontza", a round, relatively shallow cooking-pot, made of clay and goats'hair, used nowadays in the Thessalian plain (Gourgiotis, ibid.). Wood, on the other hand, in some regions (Barnard and Kristoferson 1985, p.77), including areas in Greece (the plain of Thessaly, see Gourgiotis 1994, p.207) is not easily obtainable or /and affordable. In the mountainous areas of western Thessaly, this fuel source is available and associated to a different type of cooking facility, the built, domed oven (Gourgiotis, ibid. p. 207). At present differences in cooking facilities, fuel and cooked product have not been systematically examined in order to investigate the influence of the first two on the cooked product and their relationship to scale of production. Clearly, a detailed ethnographic and experimental investigation of these variables could yield some interesting and useful results which could then be used in the interpretation of cooking 
facilities, fuel and cooked product (a rarity!) in the archaeological record. It may be possible to identify the kind of fuel used at archaeological sites by examining the composition of archaeobotanical samples and the ratio of wood charcoal to chaff in each sample. Samples, dominated by chaff and straw fragments, and associated with hearths or ovens could indicate the baking regime and thus limit the range of possibilities for the baked /cooked product. Such information is not at present available from the sites under study, not necessarily because they do not exist, but because the material has not been examined in this respect.

\subsection{Concluding remarks - « From crops to cuisine »}

33 A while ago Andrew Sherratt discussed the topic of «cuisine " (in the study of past societies: "we have been slow in apprehending the importance of culinary culture in early societies", "too often discussion remains at the level of subsistence" (1987, p. 83). "Elaboration of cuisine is one of the characteristics of farming societies" (Sherratt 1991, p. 55). Indeed, it would be hard to imagine that food had been left out of the communicative systems of past societies. Food is intended to provide humans with nutrients essential to their survival and well being, but it is a lot more than that. It becomes a code of communication, it is not only " good to eat " but also " good to think " (Levi-Stauss 1962). Pottery, which among other functions can serve as a recipient of food, has been used by archaeologists as a means of detecting the significance of sharing food: «... the care and skill lavished on pots suitable for eating and drinking underlines the social significance of hospitality " and « ... the widespread disappearance of decorated eating and drinking vessels ... suggests a reduced emphasis on sharing and hospitality ... » (Halstead 1994, p. 206 and 207 respectively).

34 Food can be used to bring people together but also to emphasise their differences and the place where each group belongs. It is hard to think of cereals as not forming the staples of prehistoric nutrition. Could cereals therefore have also been used by those societies as a means of emphasising social stratification? They certainly could, either by choice of certain species (e.g. bread wheat in antiquity and recent periods) or by special ways of food preparation. One could suggest that the wide spectrum of cereal species found as crops at a site, might indicate not only a risk buffering practice (Halstead 1990), but also a specialised cuisine, where different species are best suited (or classified as such) for different recipes. The wider range of species observed at Bronze Age sites of northern Greece (Halstead 1994, Andreou et al. 1996) could be seen as a hint towards culinary variety. It would be very interesting to examine the ways in which the cereals used by the prehistoric inhabitants of northern Greece, were being prepared for consumption beyond the "cleaned grain » stage, whether the way they were consumed involved just a basic « mix with water and heat» (Voigt and Katz 1986), or whether cereal preparation was at all sophisticated including grinding, parboiling, leavening, use of spices, dried fruit etc. ?

Changing food trends in the past should not be seen as an outcome solely of environmental factors. In examining, for example why spelt, bread wheat or millet (Sherrat 1991) occurred as crops in the Late Bronze Age, we could always have in mind the possibility of contacts with other people who introduce a culinary novelty either in terms of species or of the ways it can be cooked. Both spelt and millet have been found as crops further north than Greece, in central and eastern Europe (Zohary and Hopf 1994), at deposits that date slightly earlier than the species occurrence as a crop in Greece. Their 
later occurrence in northern Greek sites, may be linked to exchange networks existing in the Balkans, through which crops could have been transported in hand with artefacts. One may even wonder whether some of these species could have been « elite» crops, even if technology of the time may not have allowed for the sophisticated recipes of classical times onwards. For the time being, only two Bronze Age sites, Kastanas and Assiros, have yielded archaeobotanical evidence for these «later crops». The sites also happen to be the only ones in northern Greece for which published archaeobotanical information is available in detail. Future archaeobotanical work at Bronze Age settlements in the area would undoubtedly highlight the role of these «new »(?) crops in Bronze Age society viii.

Although we are certainly far from reconstructing prehistoric bread or cereal dishes and even more so from understanding the role of cereals in social interaction, the systematic recovery of plant remains and the examination of archaeobotanical material in relation to cooking facilities and eating equipment, could shed some light into these issues.

\section{BIBLIOGRAPHIE}

ABRAMS, H.L., 1978. " A Diachronic Review of Wheat in Hominid Nutrition ». Journal of Applied Nutrition, 30, pp. 1-2, 41-55.

ANDREOU, S., FOTIADIS, M., KOTSAKIS, K. 1996. Review of Aegean Prehistory V : The Neolithic and Bronze Age of Northern Greece. American Journal of Archaeology 100, 537-597.

AVITSUR, S. 1977. The Way to Bread : the Example of the Land of Israel. Tools and Tillage 2/4, 228-241.

BARNARD, G., and KRISTOFERSON, L., 1985. Agricultural Residues as Fuel in the Third World. Energy Information Programme, Technical Report no 4. Earthscan, International Institute for Environment and Development, The Beijer Institute, The Royal Swedish Academy of Sciences. BEsSIOS, M. and PAPPA, M., 1997. Neolithikos Oikismos Makriyialou. To Archaeologiko Ergo sti Makedonia kai ti Thraki 1993, 7, 215-222.

BOARDMAN, S. and JONES, G., 1990. Experiments on the Effects of Charring Cereal Plant Components. Journal of Archaeological Science, 17, 1-11.

BRAUN, T., 1995. Barley Cakes and Emmer Bread. In : J. Wilkins, D. Harvey and M. Dobson (eds.), Food in Antiquity. 25-37. Exeter, University of Exeter Press.

CRYsostomou, P. and CHRysostomou, Pan., 1993. Neolithikes Erevnes sta Giannitsa kai stin Periochi tous. To Archaeologiko Ergo sti Makedonia kai ti Thraki 4, 1990, 169-186. Thessaloniki. COHN, D.F. and KISLEV, M.E., 1987. Human Neurolathyrism. Adler Museum Bulletin 13, 1, 5-8. DALIANIS, K., 1993. Psichanthi gia Karpo kai Sano (Leguminosae for seed and hay). Athens, Stamoulis Publications.

Demoule, J.-P. and PERLES, C.,1993. The Greek Neolithic: A New Review. Journal of World Prehistory, $7,4,355-416$. 
DENNELL, R.W., 1976. The Economic Importance of Plant Resources represented on archaeological sites. Journal of Archaeological Science 3, 229-247.

DIMITRAKOS, D. B, 1956. Neon Lexikon Orthographikon kai Ermineftikon tis Ellinikis Glossis. Dimitrakos Publications, Athens.

EFSTRATIOU, N., 1993. Neoteres Erevnes sto Neolithiko Oikismo tis Makris. Anaskafiki periodos 1990. To Archaeologiko Ergo sti Makedonia kai ti Thraki, 1990, 4, 595-612. Thessaloniki.

FILIPPIDE, D., 1994. Public Oven-use Groups in Olymbos on Karpathos Island. In : Proceedings of the 3rd ETBA Symposium : «Our bread » from Wheat to Bread. Pilion, 10-12 April, 1992. 361-366. Athens, ETBA Cultural foundation.

Gourgiotis, L., 1994. Manifacture and Use of Bontza in Thesssalia. In : Proceedings of the 3rd ETBA Symposium : «Our bread» from Wheat to Bread. Pilion, 10-12 April, 1992. 205-211. Athens, ETBA Cultural foundation.

GRAMMENOS, D.V., PAPPA, M., UREM-KOTSOU, D., SKOURTOPOUlOU, K., GIANNOULI, E., VALAMOTI, S.M., MARANGOU, Ch., SYRIDIS, G., MARKI, E., CHRISTIDOU, R., 1992. Excavations at the Neolithic Settlement Thermi B and the Byzantine Habitation by the Prehistoric Settlement of Thermi A. Excavation Season 1989. Makedonika 18, 443-455.

HALSTEAD, P,. 1990. Waste not, Want not : Traditional Responses to Crop Failure in Greece. Rural History (1990) 1, 2, 147-164.

HALSTEAD, P., 1994. The North-South Divide : Regional Paths to Complexity in Prehistoric Greece. In : C. Mathers and S. Stoddart (eds.), Development and Decline In the Mediterranean Bronze Age. Sheffield Archaeological Monographs 8, 195-219. Sheffield, J.R. Collis Publications.

HALSTEAD, P., 1995. Late Bronze Age Grain Crops and Linear B Ideograms *65, *120, and *121. Annual of the British School at Athens, 90, 229-234.

HALSTEAD, P. and JONES, G., 1989. « Agrarian Ecology in the Greek Islands : Time Stress, Scale and Risk ». Journal of Hellenic Studies, 109, 41-55.

Hillman, G., 1981. Reconstructing Crop Husbandry Practices from Charred Remains of Crops. In : R. Mercer (ed.) Farming Practice in British Prehistory, 123-162. Edinburg, The University Press.

HILlman, G., 1984a. Traditional Husbandry and Processing of Archaic Cereals in Recent Times : the Operations, Products, and Equipment Which Might Feature in Sumerian Texts. Part I : the Glume Wheats. Bulletin on Sumerian Agriculture, 1, 114-152.

HILLMAN, G., 1984b. Interpretation of Archaeological Plant Remains : the Application of Ethnographic Models from Turkey. In : W. van Zeist and W.A. Casparie (eds.), Plants and Ancient Man, 1-41. Rotterdam, Balkema.

HILlmAN, G., 1985. Traditional Husbandry and Processing of Archaic Cereals in Recent Times : the Operations, Products, and Equipment That Might Feature in Sumerian texts. Part II : the FreeThreshing Cereals Bulletin on Sumerian Agriculture, 2, 1-31.

HILLMAN, G. C., MASON, S., MOULINS, D. and NESBITT, M. 1996. Identification of Archaeological Remains of Wheat : the 1992 London workshop. Circea (1996 for 1995),12 (2), 195-209.

HUBBARD, R.N.L.B.,1979. Ancient Agriculture and Ecology at Servia. Annual of the British School at Athens, 74, 226-228.

JACOMET, S. 1987. Prähistorische Getreidefunde. Basel. 
JONES, G., WARDLE, K., HALSTEAD, P., WARDLE, D., 1986. Crop Storage at Assiros. Scientific American, $254,3,96-103$.

JONES, G. and HALSTEAD, P., 1995. Maslins, Mixtures and Monocrops : on the Interpretation of Archaeobotanical Crop Samples of Heterogeneous Composition. Journal of Archaeological Science, 22, 103-114.

JONES, G., VALAMOTI, S.M. and CHARLES, M., forthcoming. A New Glume Wheat from Northern Greece.

KATZ, S.H. and voIGT, M., 1986. Bread and Beer. The Early Use of Cereals in the Human Diet. Expedition, 28, 23-34.

KNOERZER, K.-H., 1981. Auswertung von Grossrestuntersuchungen zur Aufklärung von Siedlungszusammenhängen. Zeitschrift für Archäologie, 15, 73-76.

Koukoules, Ph., 1952. Byzantinon bios kai Politismos. Athens, Papazisi Publications.

KOUKOULI-CRYSANTHAKI, Ch., 1996. Anaskafi ston Proistoriko Oikismo ton Filippon, Thesi « Dikili Tas ». Proceedings of the Archaeological Society in Athens, 1993, 137-144.

KROLL, H.J., 1983. Die Pflanzenfunde. Kastanas. Ausgrabungen in einem Siedlungshügel der Bronze- und Eisenzeit Makedoniens 1975-1979. Prähistorische Archäologie in Südosteuropa 2. Berlin, Spiess.

KROLL, H.J., 1991. Südosteuropa. In : W. Van Zeist, K. Wasylikowa and K.-E. Behre (eds.), Progress in Old World Palaeoethnobotany. 161-177. Rotterdam, Balkema.

LE CLERC, J.A., BAILEY, L.H. and WESSLING, H.L., 1918. Milling and Baking Test of Einkorn, Emmer, Spelt and Polish Wheat. Journal of American Society of Agronomy, 10, 1, 215-217.

LERCHE, G.,1981. Khubz Tannur : Freshly Consumed Flat Bread in the Near East. In : A. Fenton and T.M. Owen (eds) Food in Perspective. Proceedings of the Third International conference on Ethnological Food research, Cardiff, Wales, 1977. 179-195. Edinbourgh, John Donald Publishers Ltd.

LEVI-STRAUSS, Cl,. 1962. Totemisme: Le Totemisme aujourd'hui, Paris.

MCGEE, H., 1984. On Food and Cooking : The Science and Lore of the Kitchen. London, Allen and Unwin.

MEURERS-BALKE, J. and LUENING, J., 1992. Some Aspects and Experiments Concerning the Processing of Glume Wheats. In : P.C. Anderson (ed.) 1992, Prehistoire de l'Agriculture: Nouvelles Approches Experimentales et Ethnographiques. Monographie du CRA no 6. 341-362. Paris, Editions du CNRS.

MICHA-LAMPAKI, A., 1984. I Diatrofi ton Archaion Ellinon kata tous Arxaious Komodiographous (The diet of ancient Greeks according to the poets of comedy). PhD Thesis, Athens.

MORITZ, L.A., 1958. Grain-Mills and Flour in Classical Antiquity. Oxford, Clarendon Press.

MYLONAS, G. E,. 1929. Excavations at Olynthus, In : The Neolithic Settlement. Baltimore, John Hopkins Press.

NeSBITT, M. and SAMUel, D., 1996. From Staple Crop to Extinction? The Archaeology and History of the Hulled Wheats. In : Padulosi S., K. Hammer and J. Heller (eds.) 1996. Hulled wheats. Promoting the Conservation and Use of Underutilised and Neglected Crops, 4. Proceedings of the First International Workshop on Hulled wheats, 21-22 July 1995, Castelvecchio Pascoli, Tuscany,Italy. 41-100. Rome, International Plant Genetic Resources Institute. 
NESBitT, M., HILlMAN, G., PENA-CHOCARRO, L., SAMUEL, D., and SZABO, A.T. 1996. Checklist for Recording the Cultivation and Uses of Hulled Wheats. In : Padulosi S., K. Hammer and J. Heller (eds.) 1996. Hulled wheats. Promoting the Conservation and Use of Underutilised and Neglected Crops, 4. Proceedings of the First International Workshop on Hulled wheats, 21-22 July 1995, Castelvecchio Pascoli, Tuscany,Italy. International Plant Genetic Resources Institute, Rome. 234-245.

PALMER, R., 1992. Wheat and Barley in Mycenaean Society. In :J.-P. Olivier (ed.), Mykenaika: actes $\mathrm{du} 9 \mathrm{e}$ Colloque Internationale sur les Textes Myceniens et Egeens. 475-491. BCH supp. 25, Paris. PERISTERI, K. and TOULOUMIS, K,. 1994. Anaskafi ston Arkadiko Dramas 1991 : prokatarktikes paratirisis gia tin organosi kai ti chrisi tou xorou me vasi ti diakrisi esoterikon kai exoterikon choron. To Archaeologiko Ergo sti Makedonia kai ti Thraki, 5, 359-369. Thessaloniki.

PilAli-PAPASTeriou, A., PAPAEFTHYMiou-PAPANTHIMOU, A., KOTSAKis, K., SAVOPOUlou, Th. ,1983. Neos proistorikos Oikismos sto Mandalo D. Makedonias. International Symposium for Ancient Macedonia. Archaia Makedonia, 4, 451-465.

POLYMEROU-KAMILAKI, Aik,. 1994. Contribution to the discussion following the session on Ovens. In : Proceedings of the 3rd ETBA Symposium : «Our bread » from Wheat to Bread. Pilion, 10-12 April, 1992. 360-317. Athens, ETBA Cultural Foundation.

RENFREW, C., 1971. Sitagroi, Radiocarbon and the Prehistory of Southeast Europe. Antiquity, 45, 275-282.

RENFREW, J.,1973. Palaeoethnobotany. The Prehistoric Food Plants of the Near East and Europe. New York, Columbia University Press.

RENFREW, J., 1979. The first farmers in South East Europe. In : U. Koerber-Grohne (ed.), Festschrift Maria Hopf. Archaeo-Physika, 8, 243-265.

RIVERA NUNEZ, D. and OBON DE CASTRO, C., 1989. La Dieta Cereal Prehistorica y su Supevivencia en el Area Mediterranea. Trabajos de Prehistoria, 46, 247-254.

SAMUEL, D., 1989. Their Staff of Life : Initial Investigations on Ancient Egyptian Bread Baking. In : A. B. Lloyd (ed.), 1989. Amarna Reports, 5, Occasional Publications 6. 253-290. London, The Egypt Exploration Society.

SAMUEL, D., 1993. Ancient Egyptian Cereal Processing : Beyond the Artistic Record. Cambridge Archaeological Journal, 3, 2, 271-283.

SARPAKI, A.A., 1987. The Palaeoethnobotany of the West House, Akrotiri, Thera. A case study. PhD Thesis. Department of Archaeology and Prehistory, Sheffield University.

SHERRATT, A., 1987. Cups That Cheered. In : W. H. Waldren and R.C. Kennard (eds.) Bell Beakers of the Western Mediterranean. The Oxford International Conference 1986, Part i. B.A.R., S331(i). 81-114.

Sherratt, A., 1991. Palaeoethnobotany : from Crops to Cuisine. Paleoecologia \& Arquelogia, 2, 221-236.

VICKERY, K.F. 1936. Food in Early Greece. Illinois.

ZEIST, W. van and Bottema, S., 1971. Plant Husbandry in Early Neolithic Nea Nikomedeia, Greece. Acta Botanica Neerlandica, 20, 524-538.

ZOHARY, D. and HOPF, M., 1994. Domestication of Plants in the Old World. The origin and spread of cultivated plants in West Asia, Europe and the Nile Valley. Oxford, Clarendon Press. 


\section{NOTES}

i. The archaeobotanical material from Makri, Arkadikos, Dikili Tash, Thermi B, Makriyialos, Giannitsa B and Mandalo is currently under study and forms the basis of the author's PhD research at the Department of Archaeology, Sheffield University. Quantitative data are not given in this paper as the analysis of the material is at a very early stage.

ii. Archaeological phases and chronology for northern Greek prehistory are as follows (after Andreou et al. 1996) :

Archaeological phases Years B.C. Calendrical

Early Neolithic 6700/6500-5800/5600

Middle Neolithic 5800/5600-5400/5300

Late Neolithic 5400/5300-4700/4500

Final Neolithic 4700/4500-3300/3100

Early Bronze Age 3300/3100-2300/2200

Middle Bronze Age 2300/2200-1700/1500

Later Bronze Age 700/1500-1100

It must be pointed out that for most of the archaeobotanical information presented in this paper, only a coarse chronological framework could be used because the archaeological material is still under study.

iii. Dikili Tash has been excavated in the past and some archaeo-botanical information is already available. The information presented is based on very recent archaeological investigation of the site.

iv. All these sites have been extensively sampled for charred plant remains, with the exception of Thermi B and Giannitsa B, which are represented by few samples (30-50) due to the rescue character of the excavations.

v. In this article the word crop is used to refer to species deliberately grown and/or used at a site. It must be said that it is not possible, at least for the moment, to determine whether some of the crops identified for each site, were actually grown elsewhere and traded to the sites.

vi. At the moment, the abundance and distribution of two-row naked barley is very uncertain (M. Nesbitt, pers. comm.).

vii. A characteristic example come from vegetables. Grass pea (Lathyrus sativus), a species characterised as "poisonous" for humans (Cohn and Kislev 1987) and classified as fodder or famine food (Halstead 1990, Halstead and Jones 1989), can be found in almost every supermarket all over Greece, sold as « fava » (split peas, Jones and Halstead 1995).

viii. The only occurrence of the species as a crop in the Neolithic comes from Late Neolithic Olynthos and its association with a miniature vase reinforces in a way its rarity during that period.

\section{RÉSUMÉS}

Le «pain» préhistorique, c'est à dire la nourriture céréale de l'époque, dans les régions de Macédoine et Thrace en Grèce du nord est étudiée par l'observation des restes archéobotaniques de treize sites qui datent du Néolithique ancien (7me millénaire avant J.C.) jusqu'à l'Age du 
Bronze récent (2me millenaire B.C.) : Servia, Makriyialos, N. Nikomedeia, Mandalo, Giannitsa B, Kastanas, Assiros, Thermi B, Olynthos, Sitagroi, Arkadikos, Dikili Tash et Makri. Les possibilités d'usage de ces produits est examiné, les indications de leur utilisation comme nourriture humaine en particulier. Les manières de consommer ces céréales et les problèmes de leur observation par les données archéobotaniques sont pris en considération. Le rôle de la nourriture céréalier dans les relations sociales entre les membres d'une communauté et aussi entre des communautés est discuté. La dominance des blés vêtues (engrain et amidonnier) et de l'orge, est observé pendant le Néolithique et l'Age du Bronze. Pendant l'Age du Bronze plusieurs produits céréaliers apparaissent : épeautre, blé nu et millet. L'apparition de plusieurs produits céréaliers utilisés dans l'Age du Bronze est vue comme une conséquence potentielle des relations transculturelles et comme une indication d'une cuisine sophistiquée.

Prehistoric «bread " in the regions of Macedonia and Thrace in northern Greece is investigated through the study of charred plant remains retrieved from thirteen sites in the area dated from the Early Neolithic (7th millenium B.C.) to the Late Bronze Age (2nd millenium B.C.) : Servia, Makriyialos, N. Nikomedeia, Mandalo, Giannitsa B, Kastanas, Assiros, Thermi B, Olynthos, Sitagroi, Arkadikos, Dikili Tash and Makri. «Bread» is examined in the broad sense of cereal food. The position of each cereal species found at these sites in prehistoric human diet is investigated through the identification of cereal crops. Possible uses of these crops are examined, in particular the ways of recognising their intended use as human food. The ways of consuming these cereals is discussed together with the problems in their archaeobotanical and archaeological recognition. The social significance of cereal food within and between communities is discussed. The dominance of the hulled wheats einkorn and emmer and of barley is observed throughtout the neolithic, continuing into the Bronze Age. During the Bronze Age the range of cereals broadened with the appearance of spelt, free- threshing wheat and millet as crops. The adoption of a wider spectrum of cereal crops in the Bronze Age is viewed as a potential outcome of cross-cultural relationships and as an indicator of a sophisticated cuisine.

\section{INDEX}

Mots-clés : Pain, céréales, Macédoine, Thrace, archéobotanique

Keywords : Bread, cereals, Macedonia, Thrace, archaeobotany

\section{AUTEUR}

\section{SOULTANA-MARIA VALAMOTI}

Thessaloniki University, Greece. Actuellement/presently : Department of Archaeology and Prehistory, Sheffield University, United Kingdom. 